Jurnal Pakarena

Volume 4 Nomor 2 Desember 2019

e-ISSN: 2714-6081 dan p-ISSN: 2528-6994

\title{
Deskripsi Karya pada Tari Di Antara Dua Sisi
}

Dian Paramitha Andari ${ }^{1}$ dan Nurlina Syahrir ${ }^{2}$

Keywords :

Deskripsi;

Koreografi;

Karya Tari;

\section{Corespondensi Author}

${ }^{1}$ Mahasiswa Prodi Seni Tari, FSD UNM

${ }^{2}$ Dosen Pendidikan Sendratasik FSD UNM

\begin{abstract}
ABSTRAK
Naskah Tari dalam menciptakan karya pada mata kuliah koreografi Fakultas Seni dan Desai Universitas Negeri Makassar. Naskah Tari ini merupakan uraian tentang karya tari dengan judul "Diantara Dua Sisi" yang didalamnya menguraikan beberapa pesmasalahan, yakni 1) untuk mengetahui tingkah laku orang munafik dalam bentuk karya tari'. Metode yang digunakan dalam garapan karya tari dengan cara: proses kerja tahap awal, proses penemuan ide, pematangan alur dan tema, pemilihan dan penetapan penari, pematangan tata rias dan busana, pematangan properti dan tata rupa pentas, dan proses kerja studio terdiri dari proses penata dengan penari, proses penata dengan pemusik, proses penata dengan rias dan busana, proses penata dengan tata rupa pentas, proses penata dengan lightingman, dan proses penata dengan penata cahaya. Hasil karya ini disimpulkan bahwa: karya tari "Diantara Dua Sisi" yang menceritakan tentang manusia yang memiliki dua sifat yang berbeda dan tingkah laku orang munafik
\end{abstract}

\begin{abstract}
Dian paramitha andari: "Between the Two Sides". Dance Manuscript in creating works on the choreography course at the Faculty of Arts and Design at Makassar State University. This dance script is a description of a dance work with the title "Between the Two Sides" in which it outlines a number of problems, namely 1) to find out the behavior of hypocrites in the form of dance work'. The method used in the work of dance works by: the initial stage of the work process, the process of finding ideas, the maturation of the plot and theme, the selection and determination of dancers, the maturation of makeup and fashion, the maturation of the property and layout of the stage, and the studio work process consists of the process of arranging with dancers, the stylist process with musicians, the stylist process with makeup and clothing, the stylist process with stage layout, the stylist process with the lightingman, and the stylist process with the stylist. The results of this work are concluded that: the dance work
\end{abstract}


"Between the Two Sides" which tells about humans who have two different characteristics and the behavior of hypocrites

\section{Pendahuluan}

\section{Latar Belakang}

Manusia adalah makhluk sosial yang hidup bermasyarakat. Keutuhan manusia akan tercapai apabila manusia sanggup menyelaraskan perannya sebagai makhluk ekonomi dan sosial. Manusia dikatakan sebagai makhluk sosial karena ada dorongan dan kebutuhan untuk berhubungan (interaksi) dengan orang lain, manusia tidak akan bisa hidup sebagai manusia kalau tidak hidup di tengah-tengah masyarakat.

Interaksi sosial merupakan hubunganhubungan sosial yang menyangkut hubungan antar individu, individu dengan kelompok dan kelompok dengan kelompok. Tanpa adanya interaksi sosial maka tidak akan mungkin ada kehidupan bersama. Proses sosial adalah suatu interaksi atau hubungan timbal balik atau saling mempengaruhi antar manusia yang berlangsung sepanjang hidupnya didalam masyarakat.

Melihat kondisi sekarang banyak yang merasa dirinya sudah tidak membutuhkan orang lain lagi, ia hanya mementingkan diri sendiri (pribadi). Untuk mewujudkan keinginan pribadinya ia bahkan bersaing dan rela mengorbangkan orang lain demi keinginannya terwujud. Bahkan sekarang kita tidak bisa lagi membedakan antara orang yang benar-benar baik dan orang yang berpura-pura baik atau munafik. Munafik adalah orang yang memiliki nifak. Nifak artinya menampakkan yang baik dan menyembunyikan yang buruk. (http//:walpaperhd99.blogspot.co.id/2016/01/pengertianmunafik-ciri-ciri-unafik. html?m=1).

Beberapa penyebab munculnya sifat munafik yaitu dengki, khianat, riya' dan takabur.Dengki adalah sifat dimana seseorang tidak menyukai kelebihan atau nikmat yang ada pada orang lain, sehingga mereka berusaha untuk mendapatkan kelebihan atau nikmat orang itu sehingga nikmat itu berpindah kepadanya.

Setiap manusia yang dilahirkan tidak ada yang sempurna.Semua manusia memiliki kekurangan dan kelebihan masing-masing. Kesempurnaan adalah sesuatu yang hakiki dan kesempurnaan yang hakiki itu hanyalah milik Allah SWT.tetapi banyak manusia yang tidak bisa menerima keadaannya. Ia selalu membandingkan dirinya dengan orang lain contohnya orang lain lebih menarik, cantik, dan lebih berhasil dibandingkan dirinya sehingga timbullah sifat dengki dalam dirinya yang berusaha untuk mendapatkan kelebihan orang lain dengan berbagai cara agar kelebihan itu berpindah kepadanya. Tetapi ia juga ingin tampak baik dihadapan orang lain. Disitulah muncul kemunafikan itu yang menampakkan kebaikan dan menyembunyikan keburukannya. Akan tetapi semua perbuatan buruk pasti ada balasannya dan munafik adalah sifat yang buruk yang pasti mendapatkan balasan sesuai kadar perbuatannya. Oleh karna itu janganlah pernah memunculkan niat "munafik" dalam diri karena akan merugikan diri sendiri dan orang lain sekitarnya. "barang siapa yang mengerjakan kejahatan, niscaya akan diberi pembalasan dengan kejahatan itu dan ia tidak mendapat pelindung dan tidak (pula) penolong baginya selain dari Allah.” (QS:AnNisaa I Ayat: 123).

Berdasar latar belakang diatas, penulis tertarik mengangkat judul diantara dua sisi dengan tema kemunafikan yang menggambarkan tentang bagaimana tingkah laku orang munafik dan akibat dari sifat munafik itu sendiri.

\section{Konsep Penciptaan \\ Konsep Dasar Tari}

Karya ini menggambarkan sifat manusia serta konflik yang ada didalamnya. Penggambaran karya ini ditampilkan melalui simbol-simbol yaitu dari segi musik, kostum serta gerak tarinya. Melalui ide yang telah ada untuk mempermudah dalam proses penggarapan tari ini penata membutuhkan suatu konsep yang jelas. Adapun konsep yang dapat membantu dalam penggarapan tari adalah sebagai berikut :

\section{Rangsang Tari}

Rangsang yang digunakan dalam karya ini adalah rangsang visual.Karena berawal dari melihat tingkah laku seseorang dilingkungan sekitar kita yang memiliki dua sisi yang berbeda, ketika ia berhadapan dengan orang lain iya 
tampak baik tetapi di belakang ia memiliki akal buruk untuk mencelakai orang itu.

\section{Tema Tari}

Tema merupakan gagasan pokok dalam suatu karya tari. Tema sangat penting dalam sebuah karya tari dalam tema kita dapat menentukan judul tari. Tema muncul sesuai dengan konsep yang kita ciptakan dan tema dalam koreografi ini adalah kemunafikan. Yang menjelaskan tentang sifat manusia yang ada di sekitar kita dalam kehidupan sehari-hari yaitu sifat Munafik.

\section{Judul Tari}

Judul sangat penting dalam sebuah karya seni dan judul merupakan sebuah identitas tarian, tanpa judul, tari akan susah dimengerti dan dipahami. Judul tari adalah buah hasil dari gagasan tema yang direncanakan sehingga dapat menggambarkan isi di dalamnya. Sehingga sesuai dengan tema dalam karya ini, penata tertarik mengangkat judul "Di Antara Dua Sisi" yang menjelaskan tentang seseorang yang memiliki dua sifat atau sisi yang berbeda yaitu sisi baik dan sisi buruk.

\section{Tipe Tari}

Tipe tari yang digunakan dalam karya ini yaitu tipe tari dramatik dimana mengandung arti bahwa gagasan yang dikomunikasikan sangat kuat dan penuh daya pikat, dinamis dan banyak ketegangan, dan dimungkinkan dilibatkan konflik antara orang seorang dalam dirinya atau dengan orang lain. Seperti penggambaran dalam karya tari diantara dua sisi menceritakan tentang kecemburuan terhadap orang lain yang memiliki kelebihan dibandingkan dirinya kemudian ingin mendapatkan kelebihan itu dengan bersifat munafik yang seakan-akan ia tampak baik di hadapan orang tetapi di belakang ia memiliki akal buruk untuk menghancurkan atau mencelakai orang lain sehingga kelebihan itu berpindah kepadanya dan tidak ada lagi yang menandinginya, disitulah konflik terjadi. Tetapi niat buruknya itu berakhir sia-sia,yang ia dapat hanya penyesalan, orang-orang menjauhinya karena sifat munafiknya. ia pun sadar dengan perbuatannya dan mulai mengikuti sisi baiknya atau mulai melakukan hal-hal yang baik.

\section{Mode Penyajian Tari}

Mode penyajian yang digunakan yaitu mode penyajian tari secara simbolis. Simbolis merupakan penyajian tidak menekankan objek secara nyata tapi hanya symbol. Simbol digambarkan dalam kostum penari berwarna abuabu yang menyimbolkan kemunafikan dan simbol-simbol gerak.

\section{Proses Penciptaan \\ Proses Kerja Tahap Awal}

Proses penciptaan karya tari tentu tidak segampang apa yang dipikirkan, karena mengungkapkan suatu ide yang telah diharapkan mendapatkan berbagai tahapan guna lebih mempermantap sebuah karya dalam garapan tari.

\section{Proses Penemuan Ide}

Langkah awal proses penciptaan "Diantara Dua Sisi" dimulai dengan menentukan konsep yang akan menjadi ide mencipta, rangsangan awal yang dilakukan yaitu ide si penata dengan terinspirasi dari perilaku-perilaku manusia yang terjadi di lingkungan sekitar kemudian dikembangkan dan dijadikan sebuah karya tari. Melalui penemuan ide-ide serta rangsangan awal, penentuan tema, judul, gerak, memilih penari, pembuatan musik, penentuan tata rupa pentas serta aspek pendukung sampai selesai pada akhir pementasan.

Awalnya ide penggarapan karya tari ini dengan memperlihatkan satu kejadian ketika seseorang cemburu dengan kelebihan orang lain dan seseorang itu berada diantara dua sisi sifat yaitu baik dan buruk, namun seseorang tersebut bimbang memilih baik dengan cara bersaing secara positif atau memilih buruk dengan cara bersifat munafik yang berpura-pura baik di hadapan orang tetapi dibalik itu memiliki akal buruk. pada akhirnya seseorang itu lebih memilih sifat buruk dengan cara munafik dan setiap pilihan pasti memiliki dampak.

\section{Pematangan Alur dan Tema}

Pematangan alur dan tema yang sesuai dengan konsep garapan yang diinginkan penata yaitu dengan tema kemunafikan, yang memperlihatkan satu kejadian ketika seseorang cemburu dengan kelebihan orang lain dan seseorang tersebut berada diantara dua sisi sifat 
yaitu baik dan buruk, namun seseorang tersebut bimbang memilih baik dengan cara bersaing secara positif atau memilih buruk dengan cara bersifat munafik yang berpura-pura baik di hadapan orang tetapi dibalik itu memiliki akal buruk. pada akhirnya seseorang tersebut memilih sifat buruk dengan cara munafik. setiap pilihan pasti memiliki dampak. Melalui ide tersebut selanjutnya ditata menjadi suatu koreografi.

\begin{tabular}{|c|c|c|}
\hline NO & ADEGAN & KETERANGAN \\
\hline 1. & $\begin{array}{l}\text { Introductio } \\
\mathrm{n}\end{array}$ & $\begin{array}{l}\text { Penari perempuan duduk } \\
\text { bertongkat lutut dan bergerak } \\
\text { improvisasi dengan gerak- } \\
\text { gerak kecil. Masuk dua penari } \\
\text { sebagai bayangan yang } \\
\text { mengajak pemeran utama } \\
\text { untuk mengikutinya. }\end{array}$ \\
\hline 2. & Adegan 1 & $\begin{array}{l}\text { Dua penari laki-laki masuk } \\
\text { dengan bergerak rampak } \\
\text { memperlihatkan } \\
\text { kelincahannya. Masuk empat } \\
\text { penari perempuan dan } \\
\text { melakukan gerak rampak } \\
\text { bersama penari laki-laki. }\end{array}$ \\
\hline
\end{tabular}

3. Adegan 2 Dua penari perempuan melakukan gerak rampak dengan lincah tetapi satu penari yaitu pemeran utama tidak mampu melakukannya.

4.. Adegan 3 Pemeran utama mengulang gerak yang tidak mampu dia lakukan. Masuk dua penari sebagai bayangan dan bergerak improvisasi dengan mengajak pemeran utama. Pemeran utama mengikuti penari yang berada di sebelah kiri dan melakukan gerak mengisi.

5. Adegan 4 Dua penari perempuan masuk dan melakukan gerak yang sama dengan penari yang telah berada di panggung. Dua penari melakukan gerak rampak dan dua penari yang berperan sebagai bayangan melakukan gerak mengisi yang merupakan gambaran isi hati dua penari yang melakukan gerak rampak.

\begin{tabular}{|c|c|c|}
\hline 6. & Adegan 5 & $\begin{array}{l}\text { Dua penari perempuan yakni } \\
\text { pemeran utama dan penari yang } \\
\text { memiliki kelebihan. } \\
\text { Melakukan gerakan duet dan } \\
\text { pada akhirnya pemeran utama } \\
\text { mencelakai penari yang } \\
\text { memiliki kelincahan dalam } \\
\text { bergerak. }\end{array}$ \\
\hline 7. & Adegan 6 & $\begin{array}{l}\text { Empat penari masuk ke } \\
\text { panggung dengan bergerak } \\
\text { seakan-akan menghindari } \\
\text { pemeran utama. }\end{array}$ \\
\hline 8. & Adegan 7 & $\begin{array}{llr}\text { Pemeran } & \text { utama } & \text { melakukan } \\
\text { gerak tunggul dan } & \text { penari } \\
\text { lainnya } & \text { melakukan } & \text { gerak } \\
\text { rampak } & \text { yang } & \text { menjauhi } \\
\text { pemeran } & \text { utama. } & \text { Pemeran } \\
\text { utama } & \text { menyesal } & \text { dan } \\
\text { melakukan gerak improvisasi } & \text { imakn } \\
\text { dengan memasang } & \text { kostum } \\
\text { berwarna putih. }\end{array}$ \\
\hline 9. & Adegan 8 & $\begin{array}{l}\text { Pemeran utama berjalan ke } \\
\text { sudut panggung, penari lainnya } \\
\text { berlar merangkul pemeran } \\
\text { utama dan melakukan gerak } \\
\text { rampak kemudian berpose } \\
\text { merangkul pada ending tarian }\end{array}$ \\
\hline
\end{tabular}

\section{Penetapan dan Pemilihan Penari}

Pemilihan dan penetapan penari yang digunakan dalam karya ini beberapa kali mengalami pergantian penari. Dikarenakan ada yang mengalami kendala seperti sulitnya mengatur waktu kerja dengan latihan. Namun kemudian telah mendapatkan penari pengganti dan menjadi enam penari. Penari yang dipilih bisa berekspresi marah dan sedih. Agar pesan yang diceritakan dikarya ini bisa tersampaikan ke penonton. Dengan demikian setelah melalui pemilihan penari maka enam penari yang dipilih yaitu Dumbara, Aryanti, Nabila, Ika, Rasdy dan Hamdan.

\section{Proses Kerja Studio}

Proses kerja studio dilakukan pada saat penataan dan mengolah gerak hingga mentransfer gerak pada penari. Proses kerja studio mencakup semua proses dalam perancangan tari hingga pendalaman suatu karya sebelum melakukan pementasan. 


\section{Proses penata dengan penari}

Proses pada tahap ini merupakan proses yang sangat penting untuk pembentukan suatu karya tari. Tahap awal yang dilakukan oleh penata tari yaitu melakukan improvisasi mencari gerak-gerak yang sesuai dengan karya Diantara dua sisi, kemudian mentransferkan gerak ke penari, sebelum mentransfer gerak, penata tari menjelaskan terlebih dahulu kepada penari tentang konsep dan alur dari karya ini. Sehingga penari lebih mudah menjiwai gerak tersebut.

Namun ada beberapa kendala dalam proses mentransfer gerak ke penari salah satunya waktu setiap penari berbeda-beda, waktu penari yang tidak sama membuat latihan menjadi tidak efektif.

Setelah berjalannya proses latihan penata beberapa kali mengganti penari laki-laki. Penari laki-laki memang tidak terlalu berperan penting dalam karya ini, walaupun hanya sebagai pelengkap tetapi pemilihan penari laki-laki harus dilihat juga dari kelenturan dan kelincahannya. Pada awalnya penata memilih dua penari laki-laki yaitu Rasdy dan Didit. Dengan berjalannya waktu Didit jarang mengikuti latihan dikarenakan terhambat oleh kerja dan berbagai alasan yang menurut penata itu menghambat latihan sehingga penata memutuskan untuk mengganti Didit.

Untuk mencari penari laki-laki cukup sulit karena di FSD sangat minim penari laki-laki. Penata sempat memikirkan untuk menghilangkan penari laki-laki di karya Diantara Dua Sisi tetapi penata memikirkan proses dari penari laki-laki yang aktif yaitu Rasdy yang selalu meluangkan waktunya untuk latihan. Setelah mencari penari laki-laki akhirnya penata menemukan penari lakilaki yaitu Robby yang masih berstatus pelajar. Pada saat latihan pertama penari laki-laki pengganti ini sangat giat untuk mempelajari gerak Diantara Dua Sisi meskipun sangat sulit untuk mendapatkan teknik dari geraknya. Namun Setelah beberapa kali latihan penata sangat sulit menghubungi penarinya dikarenakan telepon yang Robby gunakan rusak, robby juga tidak memiliki kendaraan dan berbagai macam kendala sehingga Robby jarang mengikuti proses transfer gerak atau latihan. Akhirnya penata memutuskan untuk mencari penari laki-laki yang lain. Dengan waktu kurang lebih satu minggu untuk RunTrough akhirnya penata mendapatkan penari yaitu Hamdan. Disitulah proses latihan mulai lengkap semua penari sampai hari pada saat resital.

\section{Proses Pematangan Musik}

Pada awalnya musik yang digunakan yaitu musik audio tetapi pada saat konsultasi pertama dengan pembimbing ada beberapa masukan salah satunya yaitu musik yang digunakan lebih mendukung jika menggunakan music live.

Sebelum menggarap musik untuk tari Diantara dua sisi terlebih dahulu penata menjelaskan alur dari karya ini sehingga pemusik lebih mudah untuk menggarap musik peradegannya.

Pada konsul pertama menggunakan musik ada beberapa musik yang diubah pada bagian awal yang seharusnya lebih menonjolkan suasana damai dan pada adegan menyesal musik yang harus digunakan slow dan menggunakan biola. Pada Run-trough 1 musik yang diguanakan sudah sesuai dengan tarian Diantara dua sisi.

Saat Run-Trough ke2 gerak tari Diantara dua sisi bertambah pada bagian akhir sehingga music yang digunakan juga bertambah dan beberapa bagian diubah sesuai gerak tari.

\section{Proses Pematangan Tata Rias dan Busana}

Rias yang diaplikasikan pada wajah penari yaitu rias realis dengan mempertegas atau mempertebal garis-garis wajah, dimana penari tetap menunjukkan wajah aslinya tapi sekaligus mempertajam ekspresi dari karakter tarian yang dibawakan dan rambut penari diikat tengah, bagian bawah terurai agar bisa menutupi ikatan baju.

Adapun busana yang merupakan penunjang penampilan dalam suatu pertunjukan tari. Pada konsul keempat satu penari mengenakan kostum dengan memakai manset panjang berwarna kulit di tutupi dengan kemben kemudian dibalut kain putih dan diikat di lehar. Celana yang digunakan celana panjang berwarna putih berbentu celana Aladdin dan memakai topeng hitam, putih. Namun setelah konsultasi, ada beberapa masukan dari pembimbing sehingga terjadi perubahan kostum yaitu manset yang dipotong berbentuk cansee, model celana yang hanya lurus ke bawah. Pada saat run-throught kedua ada kostum yang sedikit diubah bagian celana yang terlihat kecil dibagian pinggul yang kemudian di ubah menjadi celana kulot. 


\section{Proses Penetapan tata rupa pentas}

Pada awalnya tata rupa pentas yang digunakan dalam karya ini yaitu setting kain putih yang akan dibentangkan di depan background yang akan dijadikan sebagai alat untuk menghasilkan siluet, akan tetapi beberapa pertimbangan dan masukan kepada penata sehingga penata memilih tidak menggunakan siluet.

\section{Proses penetapan tata cahaya}

Tata cayaha yang digunakan pada garapan tari ini yaitu pada awal adegan menggunakan followspot yang berfokus pada titik jari yang bergerak kemudian di perbesar dan mengikuti gerakan penari. Pada saat konflik menggunakan cahaya berwarna merah yang menggambarkan amarah dan ending kembali menggunakan followspot. Tetapi followspot yang digunakan pada saat resital tidak sesuai dengan yang penata inginkan dikarenakan followspot yang digunakan tidak bisa berfokus pada satu titik kecil.

\section{Run-Trough \\ Run-Trough 1}

Run-Trough pertama persiapan koreografi dan musik sudah matang ditambah salah satu penari memakai kostum sebagai penunjang tarian.Pada hal ini saat Run-Trough pertama beberapa koreksi dan masukan yang disampaikan oleh dosen pembimbing dan penguji mengenai gerak dan kostum.Masukan dan koreksi yang disampaikan yakni gerak penari bayangan hitam dan putih dibedakan, penari dengan bayangan putih harus bergerak selembut mungkin.Ending pada tarian ini dinamikanya menurun yang seharunya naik atau meningkat.Dan kurangnya kekompakan saat gerak rampak.

Dari masukan ini penata berusaha memperbaiki gerak dan alur dari karya ini dengan menambah alur pada ending, memperhalus gerak bayangan putih dan berlatih untuk kekompakan penar

\subsubsection{Run-Trough 2}

Saat Run-Trough2 salah satu penari Diantara dua sisi sudahmemakai kostum lengkap dan make up serta menata rambut sesuai dengan konsep tarian. Pada evaluasi Run-Trough 2 beberapa masukan dari penguji yakni model celana yang kurang rapi, gerak bayangan putih lebih dilembutkan lagi, saat penari bayangan masuk panggung pada adegan tengah sebaiknya masuk beriringan tidak dari dua arah, dan pada ending sebaiknya berpose pada posisi tengah panggung atau Center stage.

Dari koreksi inilah yang membuat penari focus lagi dalam latihan. Meskipun setelah RunTrough 1 sudah tidak konsultasi lagi dengan pembimbing dikarenakan waktu yang tidak memungkinkan dan waktu pembimbing yang cukup padat.

\section{Realisasi Proses Penciptaan Penari}

Jumlah penari yang digunakan enam orang, empat perempuan dan dua laki-laki. Pemilihan penari dan jumlah penari tersebut disesuaikan dengan kebutuhan koreografi. ada yang berperan sebagai orang munafik, orang yang memiliki kelebihan, berperan sebagai bayangan, dan berperan sebagai teman dari orang munafik dan yang memiliki kelebihan.

\section{Musik}

Musik yang digunakan pada karya tari ini yaitu iringan langsung atau music live. Pemilihan music live agar suasana dalam karya tari ini bisa hidup dan lebih membantu dalam penggambaran suasana.adapun alat music yang digunakan yaitu keyboard, biola, beduk dan drum elektronik. dengan suasana awal menggunakan biola yang mengambarkan suasana damai, adegan tengah memainkan semua alat musik lebih ditonjolkan suara beduk untuk menggambarkan suasana marah. Dan pada saat ending menggunakan biola dengan tambahan efek dari alat musik lain.

\section{Rias dan busana}

Rias yang digunakan penari pada saat pementasan yaitu rias realis yang mempertegas, mempertebal garis-garis wajah dan mempertajam ekspresi dan karakter tarian yang dibawakan.

Adapun busana yang digunakan penari perempuan menggunakan baju cansee, kemben, dan rok yang dililit dan diikat di leher, menggunakan celana lebar berwarna putih. Penari cowok menggunakan baju yang tidak berlengan dan menggunakan celana pendek.

\section{Tata Cahaya}

Tata cahaya yang digunakan pada adegan awal yaitu satu cahaya yang berfokus pada satu penari (followspot). Pada adengan selanjutnya menggunakan tata cahaya yang terang berwarna 
hijau yang menggambarkan kebersamaan atau kekompakan, adengan tengah pada saat klimaks menggunakan tata cahaya yang agak redup-redup berwarna merah dan pada saat ending menggunakan lampu sorot yang berfokus kepada penari.

\section{Pertunjukan}

Akhir dari sebuah proses yang melalui beberapa tahapan dari proses konsultasi dan perubahan yang merupakan hasil dari sebuah proses koreografi yang dipertunjukkan dengan panggung proscenium yang dilaksanakan di Gedung Kesenian dengan susunan adegan sebagai berikut.

\section{Introduction}

Penari standby di panggung bergerak improvisasi yang menggambarkan bahwa manusia itu sempurna dalam hal fisik, memiliki tangan, kaki, wajah, hati dan sifat.Sifat di gambarkan dengan muncul dua penari sebagai bayangan sisi baik dan buruk.

\section{Adegan 1}

Dua penari laki-laki bergerak rampak seolah-olah memperlihatkan kelincahannya dalam menari.Kemudian masuk empat penari perempuan dengan bergerak rampak bersama penari laki-laki.

\section{Adegan 2}

Adegan kedua dua penari perempuan duet dengan memperlihatkan kelincahannya dalam menari. Akan tetapi satu penari atau si pemeran utama tidak mampu mengikuti kelincahan gerak penari yang lain. Si pemeran utama selalu jatuh dan gagal.

\section{Adegan 3}

Pemeran utama merasa cemburu dengan kelincahan atau kelebihan orang lain itu, dia selalu mencoba tetapi selalu gagal. Akhirnya pemeran utama berpikir untuk melakukan suatu hal yang bisa membuatnya menjadi kuasa dan tidak ada yang bisa menandinginya. Dia berada di antara dua pilihan apakah mengikuti sisi baiknya yang bersaing dengan orang lain dengan sportif atau memilih sisi buruknya dengan bersifat munafik yang seolah-olah baik dihadapan orang lain tetapi dibelakang memiliki rencana buruk. Dan pada akhirnya pemeran utama lebih mengikuti sisi buruknya dengan mengubah kostumnya dari kostum berwarna putih menjadi hitam.

\section{Adegan 4}

Setelah memilih mengikuti sisi buruk. Pemeran utama pun mulai membayangkan untuk mencelakai orang yang mempunyai kelebihan tersebut. Dua penari sebagai wujud asli dan dua lainnya berperan sebagai bayangan dari dua penari tersebut.

\section{Adegan 5}

Pemeran utama mulai menampakkan sifat munafiknya yang berpura-pura baik di hadapan orang yang memiliki kelebihan tetapi setelah membelakangi, pemeran utama mencoba mencelakainya.

Adegan 6

Setelah mencelakai orang yang mempunyai kelebihan. Pemeran utama pun ketahuan oleh teman-temannya (penari-penari). Dan akhirnya temannya mulai menjauhi si pemeran utama.

\section{Adegan 7}

Pemeran utama pun menyesal dengan perbuatannya dan kembali menuju ke arah yang baik dengan memasang kembali baju putih yang ia lepas.

\section{Adegan 8}

Setelah pemeran utama menyesal dan kembali ke sisi yang baik, penari-penari lain mulai merangkulnya dan kembali kompak seperti semula.

\section{Kesimpulan}

Proses penggarapan karya ini memberikan pelajaran kepada penata tentang bagaimana cara menghargai proses, bagaimana tentang penata tari bekerja sama yang baik dengan banyak orang dengan karakter yang berbeda-beda, bagaimana tentang menghadapi tantangan dan cara mengatasi kesulitan yang ada pada saat proses penggarapan berlangsung. Penata juga belajar tentang mentransfer gerak dengan baik kepada para penari yang memiliki karakter yang berbedabeda saat prosesnya tersebut seperti ada penari yang cepat tangkap gerak dan penari yang kurang cepat tangkap gerak.

Suatu penggarapan karya, sangat membutuhkan totalitas dan kesabaran untuk mewujudkan karya tari Diantara Dua Sisi. Banyak hubungan kerja sama dengan beberapa pendukung karya tari seperti penari, pemusik, lightingman, penata rias dan busana, serta temanteman seperjuangan yang saling membantu. Komunikasi juga sangat diperlukan untuk 
membantu kerja sama yang baik selama proses yang membutuhkan waktu yang cukup lama.

Proses penggarapan karya ini memberikan pelajaran kepada penata dan penonton agar tidak cemburu terhadap kelebihan orang lain karena setiap manusia pasti memiliki kelebihan dan kekurangan. Dan sebelum bertindak atau melakukan sesuatu terlebih dahulu memikirkan dampak dan konsekuensinya. Karena setiap apa yang dilakukan pasti memiliki efek atau dampak dari apa yang diperbuat.

\section{DAFTAR PUSTAKA}

Hawkins, Alma M. 2003. Moving Form Withing a New Method For Dancing Making, Bergerak Menurut Kata Hati. Terj.Wayan Dibia. Bandung: MSPI.

Murgiyanto Sal. 2016. Kritik Pertunjukan dan Pengalama nKeindahan. Jakarta: PASCAiKJ.

Hadi, Sumandiyo Y. 2007. Kajian Tari Teksdan Konteks. Yogyakarta: Pustaka Book Publisher.

, 2016.Koreografi Bentuk Tehnik Isi. Yogyakarta: Cipta Media.

, 2012.Seni Pertunjukan dan Masyarakat Penonton (Cetakan 1).Yogyakarta: BP Isi Yogyakarta.

Meri La. 1986. Elemen - elemen Dasar Komposisi Tari (Cetakan 1). Yogyakarta: Lagaligo untuk fakultas kesenian Institut Seni Indonesia Yogyakarta. 